Citri, N. \& Grossowicz, N. (1955). J. gen. Microbiol. 13, 273-278

\title{
A Partially Defined Culture Medium for Trypanosoma cruzi and some other Haemoflagellates
}

\author{
By N. CITRI ANd N. GROSSOWICZ \\ Department of Bacteriology, Hebrew University-Hadassah \\ Medical School, Jerusalem, Israel
}

\begin{abstract}
SUMMARY : A partially defined medium for cultivation of blood flagellates has been developed. In this medium blood was replaced by haematin, crystalline serum albumin and a series of simple growth factors. The medium supported growth of Trypanosoma cruzi, Leishmania tropica, and a few other strains of Trypanosomidae. The growth on this medium was comparable to that obtained on optimal bloodcontaining media; no change in growth was found after prolonged serial subcultivation.
\end{abstract}

The failure to propagate haemoflagellates in the absence of erythrocytes (Little \& Oleson, 1951) or serum (Lwoff, 1951) has been a major obstacle in analysing the nutritional requirements and metabolic activities of this important group of parasites. A medium in which blood was replaced by tomato juice, bovine albumin and haematin, was described briefly by Citri \& Grossowicz (1954a). The tomato juice has now been replaced by a number of known growth factors. Thus a medium is at hand which supports optimal growth of Trypanosoma cruzi and other haemoflagellates under partially defined conditions and which permits a better analysis of the growth requirements of these organisms.

\section{METHODS}

Organisms. All the organisms used in this work were kindly provided by Prof. S. Adler (Jerusalem). The strain of Trypanosoma cruzi now used (Culbertson strain) was obtained in 1949 from Dr T. S. Hauschka (Philadelphia) who kept it on Senekjie's (1943) medium. The strains had been maintained in the Department of Parasitology, Hebrew University, Jerusalem, on Adler's medium (Adler \& Theodor, 1926) before the present work.

Stock diphasic medium. At the beginning of this work a satisfactory modification (Table 1) of the diphasic medium of Chang (1947) served as a source of cells for nutritional studies. It was made up as follows: solution (B) $(20-25 \mathrm{ml}$.) was dispensed in $100 \mathrm{ml}$. Erlenmeyer flasks, autoclaved $15 \mathrm{lb} / \mathrm{sq} . \mathrm{in}$. pressure for $20 \mathrm{~min}$. and allowed to harden in upright position to form a solid base. This base was overlaid with $15 \mathrm{ml}$. of solution (C).

Stock liquid medium. In the course of this work a simpler medium (TJ) was developed, in which a mixture of tomato juice, haematin and crystalline serum-albumin completely replaced blood. The composition of this medium was as follows: $\mathrm{NaCl}, 0 \cdot 4 \mathrm{~g}$.; $\mathrm{Na}_{2} \mathrm{HPO}_{4} .12 \mathrm{H}_{2} \mathrm{O}, 0 \cdot 3 \mathrm{~g}$.; $\mathrm{KH}_{2} \mathrm{PO}_{4}, 0.05 \mathrm{~g}$.; casein hydrolysate (enzymic, Bios Laboratories, Inc., New York), 1.0 g.; distilled 
water to $95 \mathrm{ml}$. This was autoclaved. To this autoclaved basal part of the medium were then added aseptically sterile haematin $1.0 \mathrm{mg}$. in $1 \mathrm{ml}$.; bovine albumin fraction V (Armour Laboratories, Chicago), $50 \mathrm{mg}$. in $1 \mathrm{ml}$; tomato juice, $\mathbf{3} \cdot 0 \mathrm{ml}$. The final volume was $100 \mathrm{ml}$.

Table 1. Stock diphasic medium

Solution A

Neopeptone (Difco)
Beef extract (Bovril)
Glucose
$\mathrm{NaCl}$
$\mathrm{KH}_{2} \mathrm{PO}_{4}$
$\mathrm{Na}_{2} \mathrm{HPO}_{4} .12 \mathrm{H}_{2} \mathrm{O}$
$\mathrm{H}_{2} \mathrm{O}$ distilled

$\mathrm{pH} \mathbf{7} \cdot \mathbf{8}$
Solution B

\begin{tabular}{rlr}
$20 \cdot 0 \mathrm{~g}$. & Solution (A) & $600 \mathrm{ml}$ \\
$6 \cdot 0 \mathrm{~g}$. & Agar-agar & $9 \cdot 0 \mathrm{ml}$ \\
$2 \cdot 0 \mathrm{~g}$. & Human haemoglobin solution* & $30 \mathrm{ml}$ \\
$4.0 \mathrm{~g}$. & \multicolumn{2}{c}{ Solution C (liquid } \\
$0.5 \mathrm{~g}$. & Solution (A) & $400 \mathrm{ml}$. \\
$3.0 \mathrm{~g}$. & ACD human plasma $\dagger$ & $40 \mathrm{ml}$ \\
$1000 \mathrm{ml}$. & Tomato juice & $8 \mathrm{ml}$. \\
& Penicillin & $24 \mathrm{mg}$. \\
& Streptomycin & $40 \mathrm{mg}$.
\end{tabular}

* Prepared by laking 1 vol. of erythrocytes (human) in 3 vol. of distilled water; the ghost cells are removed by centrifugation.

$\dagger$ Both erythrocytes and plasma were obtained from citrated (ACD) blood batches discarded by the Blood Bank.

$\ddagger$ The juice was squeezed from ripe tomatoes, strained through gauze, filtered through paper and then Seitz filtered.

The TJ medium served subsequently as a stock medium for Trypanosoma cruzi and Leishmania tropica and as a starting-point for the compounding of the partially defined medium to be described. The TJ medium and other media derived from it were dispensed in $5 \mathrm{ml}$. lots in $18 \times 150 \mathrm{~mm}$. test tubes, optically matched for turbidimetric measurements.

Growth determination. Cultures were incubated at $28^{\circ}$ sloped at an angle of $15^{\circ}$ from the horizontal. Growth was determined at intervals of 3 days by direct measurement of the optical density at wavelength $650 \mathrm{~m} \mu$. in a Coleman Junior spectrophotometer. The correlation between optical density and number of cells/ml. culture fluid was established by comparing turbidity measurements with haemacytometer counts of cultures at different time intervals. An increase of $0 \cdot 1$ on the optical density scale was found to represent an average increase of $1.6 \times 10^{8}$ cells $/ \mathrm{ml}$.

\section{RESULTS}

In replacing tomato juice by known growth factors we have followed the few analyses of this product (Cheldelin \& Williams, 1942; Grossowicz, 1944), although some of the factors which proved necessary were not known to be supplied by tomato juice. The list of growth factors which was found to replace the tomato juice moiety is given in Table 2. Each of these factors appears to be indispensable for propagation of Trypanosoma cruzi. The partially defined medium whose composition is given in Table 2 was made up as follows: ingredients were dissolved in glass distilled water, the reaction adjusted to $\mathrm{pH} 7.8$ and the medium autoclaved at $15 \mathrm{lb} / \mathrm{sq}$.in. pressure for $20 \mathrm{~min}$; the components, marked by $\left(^{*}\right)$ in Table 2 , were dissolved separately, sterilized by filtration through Seitz pads, and added aseptically to the cooled medium. 
Penicillin $(60 \mu \mathrm{g} . / \mathrm{ml}$.) and streptomycin $(100 \mu \mathrm{g} . / \mathrm{ml}$.) were included to decrease the risk of bacterial contamination.

Growth of Trypanosoma cruzi on the partially defined medium. The rate of growth and the final yield of Trypanosoma cruzi on the new medium is equivalent to that previously described (Citri \& Grossowicz, 1954 a) for the TJ medium and compares favourably with that obtained on undefined empirical media commonly employed for cultivation of this parasite (Table 3 ).

\section{Table 2. Composition of the partially defined medium}

Growth factors replacing tomato juice in $\mathbf{T J}$ medium

\begin{tabular}{|c|c|c|c|c|c|}
\hline \multirow[b]{2}{*}{ Basal medium } & \multirow[b]{2}{*}{ g./l. } & & & & \\
\hline & & \multicolumn{3}{|c|}{$\mu \mathrm{g} . / \mathrm{ml}}$. & $\mu \mathrm{g} . / \mathrm{ml}$ \\
\hline $\mathrm{NaCl}$ & $4 \cdot 0$ & $p$-Aminobenzoic acid & $0 \cdot 1$ & Riboflavin* & $1 \cdot 0$ \\
\hline $\mathrm{Na}_{2} \mathrm{HPO}_{4} \cdot 12 \mathrm{H}_{2} \mathrm{O}$ & $3 \cdot 0$ & Biotin & $0 \cdot 2$ & Thiamine* & $1 \cdot 0$ \\
\hline $\mathrm{KH}_{2} \mathrm{PO}_{4}$ & 0.5 & Choline & $3 \cdot 0$ & Cobalamin & $0 \cdot 0001$ \\
\hline $\begin{array}{l}\text { Casein hydrolysate } \\
\text { (enzymic) } \dagger\end{array}$ & $10 \cdot 0$ & Folic acid & $2 \cdot 5$ & Ribonucleic acid & 80 \\
\hline $\begin{array}{l}\text { Crystalline serum } \\
\text { albumin* }\end{array}$ & $2 \cdot 0$ & Inositol & $150 \cdot 0$ & Cytidylic acid & 20 \\
\hline Glucose* & $\mathbf{2 \cdot 0}$ & Nicotinamide & $15 \cdot 0$ & Creatine & 20 \\
\hline & mg. $/ 1$. & Pyridoxin & $\mathbf{2} \cdot \mathbf{0}$ & Creatinine & 20 \\
\hline Haematin* & $10 \cdot 0$ & Pyridoxal & $2 \cdot 0$ & & \\
\hline Tween 80 & $10 \cdot 0$ & Pyridoxamine & $2 \cdot 0$ & & \\
\hline
\end{tabular}

* Seitz-sterilized and added aseptically to the autoclaved medium; final concentration as indicated above.

$\dagger$ A product of Bios Laboratories Inc., purified by adsorption on charcoal at pH 4.5.

Table 3. Comparison of yields of Trypanosoma cruzi grown in different media

\begin{tabular}{|c|c|c|c|c|}
\hline $\begin{array}{l}\text { Type of } \\
\text { medium }\end{array}$ & $\begin{array}{c}\text { Essential } \\
\text { blood components }\end{array}$ & $\begin{array}{l}\text { Supplemented } \\
\text { with }\end{array}$ & $\begin{array}{l}\text { Final yield } \\
\text { cells } / \mathrm{ml} \\
\times 10^{7}\end{array}$ & Authors \\
\hline Semisolid & Serum & Meat extract & $3 \cdot 0$ & Adler, 1934 \\
\hline Diphasic & $\begin{array}{l}\text { Erythrocytes and } \\
\text { serum }\end{array}$ & Liver extract & $7 \cdot 0$ & Chang, 1947 \\
\hline Diphasic & $\begin{array}{l}\text { Heated haemo- } \\
\text { globin }\end{array}$ & Undefined factors & $1 \cdot 2$ & $\begin{array}{r}\text { McRary, Noble \& } \\
\text { Tondevold, } 1952\end{array}$ \\
\hline Diphasic & $\begin{array}{l}\text { Erythrocytes } \\
\text { coagulum }\end{array}$ & Undefined factors & $0 \cdot 1$ & Little \& SubbaRow, 1945 \\
\hline Liquid & $\begin{array}{l}\text { Haemin and } \\
\text { crystalline serum } \\
\text { albumin }\end{array}$ & Tomato juice & $5 \cdot 0$ & Citri \& Grossowicz, 1954a \\
\hline Liquid & $\begin{array}{l}\text { Haemin and } \\
\text { crystalline } \\
\text { serum albumin }\end{array}$ & $\begin{array}{l}\text { Defined factors } \\
\text { (see Table 2) }\end{array}$ & $5 \cdot 0$ & present paper \\
\hline
\end{tabular}

Trypanosoma cruzi has now been carried on the partially defined medium through twenty-seven serial subcultures covering a period of one and a half years. Serial transfers were made at 3 -weekly intervals, although the cells remained viable and motile for much longer. As no diminution in growth nor any other anomaly in development of the flagellate was detected during this period, it seems permissible to conclude that the present medium satisfies all the nutritional requirements of $T$. cruzi. 
The possibility that the excellent growth described was due to the selection of a less exacting variant, which occurred during the intermediate stages of the present work, was next considered. Washed cultures of Trypanosoma cruzi, never previously grown in the absence of blood or serum, were sown into the present medium. The resulting growths were equal to those obtained with the strain which had been cultivated for over 2 years without blood; no decrease in growth was found in serial subcultures designed to eliminate any carry-over of the original medium.

Growth of other Trypanosomidae on the partially defined medium. Forty-three strains belonging to the family Trypanosomidae were tested for their ability to grow on the new medium; the results are summarized in Table 4.

Table 4. Growth of various Trypanosomidae on the partially defined medium

\begin{tabular}{|c|c|c|c|}
\hline Species & $\begin{array}{l}\text { No. of } \\
\text { strains } \\
\text { tested }\end{array}$ & $\begin{array}{l}\text { Average count* } \\
\text { (cells/ml.) } \\
\times 10^{7}\end{array}$ & Remarks \\
\hline Leishmania tropica & 31 & $\mathbf{3 \cdot 2}$ & $\begin{array}{l}\text { Rate of growth varies for dif- } \\
\text { ferent strains }\end{array}$ \\
\hline L. infantum & 4 & - & Died off on second subculture \\
\hline$L$ L. sp. (from reptiles) & 4 & $2 \cdot 6$ & $\begin{array}{l}\text { Two strains died off on second } \\
\text { subculture }\end{array}$ \\
\hline Trypanosoma lewisi & 1 & - & $\begin{array}{l}\text { This strain required added } \mathbf{R B C} \\
\text { on Adler's medium (Adler, 1934) }\end{array}$ \\
\hline T. cruzi & 1 & $5 \cdot 0$ & - \\
\hline T. acomys & 1 & $5 \cdot 1$ & - \\
\hline Herpetomo & & $9 \cdot 6$ & dity in $24 \mathrm{hr}$. \\
\hline
\end{tabular}

\footnotetext{
*Where numbers are stated, no change in rate of growth or final count was observed during
} 10 serial transfers made to date.

\section{DISCUSSION}

The present medium differs from other media hitherto employed for serial subculture of haemoflagellates both in its physical and in its chemical constitution. Like the TJ medium previously described, it is free from insoluble constituents such as the agar included in most media (Adler \& Theodor, 1926; Chang, 1947; Johnson Tobie \& Rees, 1948; Seneca \& Henderson, 1951; McRary, Noble \& Tondevold, 1952), or erythrocyte coagulum (Little \& SubbaRow, 1945, Little \& Oleson, 1951). Despite elimination of all particulate components, optimal physical conditions are maintained by the simple device of incubating the culture tube sloped at an angle of $15^{\circ}$. The effect of the surface/volume ratio on the growth of various species of Leishmania, Trypanosoma cruzi and Herpetomonas culicidarum has already been recognized (Chang, 1947; Cowperthwaite, Weber, Packer \& Hutner, 1953), and it cannot be attributed solely to improved aeration of the culture, since shaking or bubbling does not give similar results. Investigation of the physical factors conditioning growth of these flagellates may be greatly facilitated by making use of the liquid medium described above.

In replacing tomato juice by known growth factors, the chemical composition of the medium has become more defined. Surprisingly enough, the 
particular requirements of blood flagellates thriving on this medium proved to be much simpler than anticipated (Little \& Oleson, 1951; Hamilton, Hutner, Provasoli, 1952; McRary et al. 1952; Kidder, 1953). A discussion of the total growth requirements of these organisms has obviously to be postponed until a minimal and completely defined medium is devised. Experiments now in progress indicate that the commercial casein digest included in the present medium may be replaced by a mixture of amino acids, with higher concentrations of some of the growth factors already recognized.

Another point which requires further study is the need for serum albumin.* The function of albumin in the present medium may perhaps be fully explained by its capacity to serve as a detoxifying vehicle of an essential lipid, namely oleic acid (Citri \& Grossowicz, 1954 $b$ ). The composition of the present medium may serve as a basis for the study of the nutritional requirements of the other Trypanosomidae whose growth it can support. Apart from its nutritional implications, the new medium provides suitable conditions for evaluation of trypanocidal agents, where defined composition and photometric growth determination is of advantage. The medium may also serve as a rich, convenient and less complicated source of cells for metabolic, cytochemical and antigenic studies.

This paper forms part of a Ph.D. Thesis presented by N. Citri to the Hebrew University, Jerusalem.

Our thanks are due to Prof. S. Adler (Jerusalem) for the strains employed in this work, and for his constant interest in the progress of the present investigation.

\section{REFERENCES}

Adler, S. (1934). Culture of Leishmaniae and other Trypanosomidae in haemoglobin-free media. Trans. R. Soc. trop. Med. Hyg. 28, 201.

Adler, S. \& Theodor, O. (1926). The identity of Leishmania tropica and Herpetomonas papatasii. Ann. trop. Med. Parasit. 20, 355.

Chang, S. L. (1947). Studies on haemoflagellates. I. A semi-solid medium and a fluid medium with a solid base for growing various species of Leishmania and Trypanosoma cruzi. J. infect. Dis. 80, 164.

Cheldelin, V. H. \& Williams, R. J. (1942). The B vitamin content of foods. Univ. Tex. Publ. no. 4237, 105.

Citri, N. \& Grossowicz, N. (1954a). A liquid medium for the cultivation of Trypanosoma cruzi. Nature, Lond. 173, 1100.

Crtri, N. \& Grossowicz, N. (1954,b). The function of blood in the cultivation of Trypanosoma cruzi. Bull. Res. Coun. Israel, 4, 210.

Cowperthwaite, J., Weber, M. W., Packer, L. \& Hutner, S. H. (1953). Nutrition of Herpetomonas (Strigomonas) culicidarum. Ann. N.Y. Acad. Sci. 56, 972.

Grossowrcz, N. (1944). Growth requirements and metabolism of haemolytic streptococci, pneumococci and meningococci in synthetic media. A thesis for the degree of Ph.D. Hebrew University, Jerusalem, Palestine.

Hamilton, L. D., Hutner, S. H. \& Provasoli, L. (1952). The use of protozoa in analysis. Analyst, 77, 618.

Johnson Tobie, E., \& ReEs, W. R. (1948). The cultivation of Trypanosoma cruzi in dialysate medium. J. Parasit. 34, 2.

* See p. 278 addendum. 
KIDDER, G. W. (1953). The nutrition of invertebrate animals. In Biochemistry and Physiology of Nutrition, 2. Ed. G. H. Bourne and G. W. Kidder. New York: Academic Press Inc.

Littre, P. A. \& SubbaRow, Y. (1945). A practical liquid medium for cultivation of Trypanosoma cruzi in large volumes. J. Bact. 50, 57.

Little, P. A. \& Oleson, J. J. (1951). The cultivation of Trypanosoma cruzi. J. Bact. 61, 709.

Lwoff, M. (1951). The nutrition of parasitic flagellates. In Biochemistry and Physiology of Protozoa, 1. Ed. A. Lwoff. New York: Academic Press Inc.

McRary, W. L., Noble, E. R. \& Tondevold, E. L. (1952). Blood factors in the nutrition of Trypanosoma cruzi. Science, 115, 288.

Seneca, H. \& Henderson, E. (1951). Growth of hemoflagellates in dialyzing sacs and the production of growth inhibitory factor. Amer. J. Hyg. 53, 17.

SenekJie, H. A. (1943). Biochemical reactions, cultural characteristics and growth requirements of Trypanosoma cruzi. Amer. J. trop. Med. 23, 523.

(Received 23 February 1955)

\section{ADDENDUM}

That albumin per se is not essential for growth of $T$. cruzi is now evident from the fact that 21 serial passages without albumin have been successfully carried out in the partially defined medium. 